\title{
UNIVERSITYOF
}

FORWARD

THINKING

WESTMINSTER用

WestminsterResearch

http://www.westminster.ac.uk/westminsterresearch

\section{Enhancing Momentum Investment Strategy Using Leverage}

Forner,C., Muradoglu, Y.G. and Sivaprasad, S.

This is the peer reviewed version of the following article: Forner,C, Muradoglu, Y.G. and Sivaprasad, S. (2018) Enhancing Momentum Investment Strategy Using Leverage, Journal of Forecasting. DOI: 10.1002/for.2522, which has been published in final form at: https://dx.doi.org/10.1002/for.2522.

This article may be used for non-commercial purposes in accordance with Wiley Terms and Conditions for Self-Archiving.

The WestminsterResearch online digital archive at the University of Westminster aims to make the research output of the University available to a wider audience. Copyright and Moral Rights remain with the authors and/or copyright owners.

Whilst further distribution of specific materials from within this archive is forbidden, you may freely distribute the URL of WestminsterResearch: ((http://westminsterresearch.wmin.ac.uk/).

In case of abuse or copyright appearing without permission e-mail repository@westminster.ac.uk 


\title{
ENHANCING MOMENTUM INVESTMENT STRATEGY USING LEVERAGE
}

\author{
Carlos Forner $^{\mathrm{a}, *}$, Yaz Gulnur Muradoglu ${ }^{\mathrm{b}}$ and Sheeja Sivaprasad ${ }^{\mathrm{c}}$
}

a," University of Alicante, Campus San Vicente del Raspeig, E-03080, Alicante, Spain. Tel: +34

965903621, e-mail: carlos.forner@ua.es

${ }^{\mathrm{b}}$ Queen Mary, University of London, Bancroft Building, Mile End, London E1 4NS. Tel :+44 (0)20 7882

6929 Fax: +44 (0)20 7882 3615, e-mail: y.g.muradoglu@qmul.ac.uk

c University of Westminster, 35 Marylebone Road, London, NW1 5LS. Tel : +44 (0)20 35066508 Fax:

+44(0)20 7911 5839, e-mail: sivaprs@wmin.ac.uk

\begin{abstract}
Previous studies examine investment strategies based on leverage and momentum; none investigate both variables jointly as an investment strategy. This paper is the first incorporating leverage and momentum together. We show that low past returns (losers) forecasts future negative abnormal returns only among stocks with high leverage levels, but not among stocks with low leverage levels. However, high past returns (winners) forecasts future positive abnormal returns independently of leverage level. As result, the negative relation between leverage and future abnormal returns is only observed among loser stocks and the positive relation between past returns and future abnormal returns is only shown among nonwinner stocks. Our results are important to achieve better investment strategies: buying winners stocks (independently of their level of leverage) and short-selling losers stocks with high leverage yield higher abnormal returns than strategies based in only one of these variables. Our two-dimension strategy yields risk adjusted abnormal returns of $15.66 \%$ per annum, while the single leverage or momentum strategies yield $7.70 \%$ and $7.96 \%$ per annum respectively. The difference is nearly $8 \%$ and economically significant. If leverage is considered as proxy for default risk, our results, contrary to previous evidence, show that momentum profits are not exclusive of default stocks, nor momentum returns are only driven by negative returns yielded by distress stocks.
\end{abstract}

Keywords: leverage, momentum, investment strategy, distress stocks, non-regulated industries JEL classification: G14, G11 


\section{ENHANCING MOMENTUM INVESTMENT STRATEGY USING LEVERAGE}

Leverage and momentum have not been studied jointly in asset pricing as the basis of abnormal returns. We bring together two asset pricing features, returns to low leverage firms and continuation of prior returns. The studies on leverage do not consider momentum; likewise, the studies on momentum do not consider leverage. It is as if these are two separate domains in asset pricing that do not overlap. We fill this gap and show that considering both dimensions to construct a new strategy yields risk adjusted abnormal returns of $15.66 \%$ per annum, while the single leverage or momentum strategies yield $7.70 \%$ and $7.96 \%$ per annum respectively

Modigliani and Miller (1958) show that the market beta of equity can be decomposed into the firm's business operation's beta (asset beta) and a factor proportional to the firm`s leverage ratio. That is, leverage amplifies the exposure of equity to priced systematic risk. Then raw equity returns should be positively related to leverage because levered equity has greater sensitivity to priced risks than unlevered equity. Accordingly, we should expect to observe higher average returns in stocks of high leveraged firms than in stocks of low leveraged firms. Various studies have documented a positive association between market leverage and stock returns at the firm level: Hamada, (1972), Bhandari (1988), Dhaliwal et al. (2006), and Gomes and Schmid (2010). However, the empirical evidence shows a different story when book leverage is used instead of market leverage. Fama and French (1992), Penman et al. (2007), Dimitrov and Jain (2008), and Korteweg (2010) find that book leverage is negatively associated with returns in the U.S. Strong and Xu (1997), and Muradoglu and Sivaprasad (2012a, 2012b) find the same negative relation in the U.K. stock market. 
If we consider leverage to be positively related with distress risk (default probability), this negative relation is consistent with the results that returns are lower for firms with greater distress intensities, the so-called "distress risk puzzle" (Dichev, 1998; Griffin and Lemmon, 2002; Campbell et al., 2008; Garlappi et al., 2008). George and Hwang (2010) analyze both leverage and distress puzzles. They find a strong negative relation between returns and leverage in raw returns, and an even stronger relation in returns adjusted for risk via the Fama and French (1993) three-factor model (hereafter, FF). Moreover, when leverage and distress are included in the same regression, leverage subsumes the explanatory power of distress in all but one of their specifications. ${ }^{1}$

Similarly, since the work of Jegadeesh and Titman (1993), price momentum has been studied by various researchers as a source of abnormal returns. Momentum refers to stocks with higher past returns (winners) over the past three to twelve months, yielding significantly positive abnormal returns in the next three to twelve months; and stocks with lower past returns (losers) over the past three to twelve months, yielding significantly negative abnormal returns in the next three to twelve months. That is, winner stocks keep on outperforming loser stocks for three to twelve month periods.

There is vast literature on momentum based investment strategies. For instance, Jegadeesh and Titman (2001) show that momentum profits persisted in the U.S. market during the nineties. Rouwenhorst (1998) finds evidence of momentum in a sample of twelve European markets. Liu et al. (1999) find that the momentum investment strategy is also profitable in the U.K. stock market. Liew and Vassalou (2000), and Chui et al.

\footnotetext{
${ }^{1}$ For George and Hwang (2010), these negative relations of returns with leverage and distress are not a puzzle. They suggest that if financial distress costs heighten exposure to systematic risk that is priced, and firms with high distress costs choose low leverage but still have greater exposure to systematic risk than firms with high leverage, in this case, expected returns are greater for firms with low leverage (default probability) than firms with high leverage (default probability).
} 
(2003, 2010) find that this phenomenon is observed in global markets, with few exceptions such as Japan. Geczy and Samanov (2016) find momentum is significant since the beginning of the $19^{\text {th }}$ century. Moreover, Fama (1998), after a deep analysis of the robustness of the methodologies used in the study of the different market anomalies, concludes that only two remain unexplained: price, and earnings momentum.

The momentum literature has also shown that this phenomenon tends to be stronger (or exclusive) of stocks with some characteristics. Daniel and Titman (1999) find that momentum is bigger in growth stocks. Hong, Lim and Stein (2000) show that momentum decrease with size and analyst coverage. Agarwal and Taffler (2008) find that momentum profits are driven by the bad return trend, earned by distress stocks. Avramov et al. (2007) provide evidence of momentum profitability to be restricted to high credit risk firms, and non-existent for firms of high credit quality.

There is also extensive literature than analyses what drives momentum. On one hand, it is argued that momentum is due to under-reaction to information (Daniel and Titman, 1999; Hong et al., 2000; Jegadeesh and Titman, 2001; Liu et al., 1999, Mao and Wei, 2014), and on the other hand, that it is risk related (Abinzano et al., 2014; Agarwal and Taffler, 2008; Avramov et al. 2007; Booth et al., 2016; Chordia and Shivakumar, 2002; Johnson, 2002; Wu, 2002).

The purpose of this study is to examine the interaction between leverage and momentum in the forecast of future returns, and their implication in the development of investment strategies. We find that negative abnormal returns are exclusive for those losers stocks that do not have low leverage ratios. Loser stocks with low leverage ratios overcome poor performance. On the contrary, positive abnormal returns are pervasive for all winner stocks independently of their leverage level. Not only winner stocks with low leverage ratios yield positive abnormal returns, but also winner stocks with high leverage 
ratios. We also find that outperformance of low leverage stocks over high leverage stocks is not observed among winner stocks; and that momentum, outperformance of winner stocks over loser stocks, is not observed among low leverage stocks.

This interaction between past returns and leverage in the forecast of future abnormal stock return performance should be considered by practitioners when developing their investment strategies in order to achieve better results. The investment strategies that buy winners stocks (independently of their level of leverage) and short-sell losers stocks with high leverage yield higher abnormal returns than strategies based in only one of these variables. For example, our two-dimension strategy yields $1.22 \%$ monthly Fama and French alphas (15.66\% in annual terms), while the single leverage strategy yields $0.62 \%$ (7.70\% in annual terms) and single momentum strategy $0.64 \%$ (7.96\% in annual terms). The difference is statistically and economically (almost $8 \%$ annually) significant.

Our results could be compared with those of Agarwal and Taffler (2008). They suggest that a negative distress premium could be due by investors underreacting to risk of failure, leading to the stock prices of such firms not being discounted sufficiently. The market anticipates, but does not fully incorporate (underreact) the deteriorating financial health of a firm; that is, the market takes time to incorporate this bad information in prices (Hong et al. 2000), generating a negative financial distress risk premium and continuation of prior bad returns (momentum in loser stocks). According to this idea, momentum profits are driven by the bad return trend, earned by distress stocks. Consistent with their hypothesis, Agarwal and Taffler (2008) find that the failure of the FF model to explain momentum is due to very negative risk-adjusted returns for distressed loser; and momentum effect is significant only for distressed firms. Agarwal and Taffler (2008) argue that credit risk and financial distress are synonymous and, therefore, interpret their 
results as consistent with Avramov et al. (2007) evidence that low credit rated stocks drive momentum. However, Avramov et al. (2007) ${ }^{2}$ distinguish between credit risk and financial distress and argue that leverage is a better proxy for distress risk.

If, as suggest Avramov et al. (2007), we consider leverage as a proxy of default risk, our analysis of the interaction between momentum and leverage show that abnormal returns come not only from the negative performance of loser stocks with high leverage (distressed), but also from positive performance of winner stocks independently of their leverage (level of distress). Therefore, the fact that winner stocks do not outperform loser stocks among the category of low leverage stocks does not mean that momentum profits are exclusive of default stocks and momentum returns are not mainly driven by the bad return trend earned by distress stocks. From practitioner's point of view, our differential results show that buying winner stocks with low leverage it is possible to achieve positive abnormal returns overcoming short-selling positions and default stocks.

We undertake two robustness analyses. First, we check the robustness of our results to non-normality, using a bootstrap analysis to compute the p-values. In particular, we use the procedure proposed by Lyon et al. (1999), who apply the bootstrap method to the t-statistic, adjusted for asymmetry, developed by Johnson (1978). Second, following Muradoglu and Sivaprasad (2012a, 2012b), Moskowitz and Grinblatt (1999), and Boni and Womack (2006), we check the robustness of the previous results for the subsample of non-regulated industries. Conclusions are robust.

\footnotetext{
2 Avramov et al- (2007) analyze stocks with credit ratings, so their sample does not include all the cross section of stocks: they only include 3,578 stocks with credit rating over a total of 13,018 stocks $(27 \%$ of the total cross section). Our analysis does not have this handicap.
} 
The rest of the paper is organized as follows: the next section describes the data and the research design; the second presents the results; and the last section concludes.

\section{Data and Research Design}

We obtain our data from Datastream. We use the capital gearing definition (Datastream code WC08221). Leverage of a company (expressed as a percentage) is defined as the ratio of total debt to total financing of the firm. We use a company's market value (Datastream code MV) to represent the company size. We define market capitalization as the closing share price, multiplied by the number of ordinary shares in issue. The market-to-book value (Datastream code MTBV) refers to a company's closing share price, divided by the book value. We group our sample firms into different sectors by using the four-digit SIC industry classification. We analyze companies listed on the London Stock Exchange (LSE) from May 1982 to April 2016. For each firm year observation, to enter the sample, we require fiscal year-end data (debt ratio, market value, and market-to-book ratio) and stock price series to be available for at least 12 months. The study excludes financial companies, including banks, investment and insurance companies, and companies that change the fiscal period's year-end date during the research period. We eliminate negative market-to-book and negative leverage ratios, as well as leverage ratios higher than $99.99 \%$. The resulting sample contains 23,599 firm year-end leverage observations and 327,924 firm monthly return observations from 1,554 companies. Table 1 shows summary statistics for the sample.

Table 1 here

To analyze whether leverage and momentum have predictive power in the crosssection of the stock market returns, a portfolio approach has been used. If leverage and momentum are relevant in explaining why stocks yield different average returns, then we 
should observe significant different average returns in portfolios constructed by these two variables. Moreover, portfolios constructed simultaneously by leverage and momentum will allow us to analyze whether one of these variables has explanatory power beyond the other, and whether the explanatory power of one of these variables is allocated in a specific segment of the other.

We construct the leverage portfolios as follows. First, at the first of July (i.e. the formation date) of each year $t$, we rank stocks by leverage on previous month of March. ${ }^{3}$ Next, we construct five equally weighted portfolios: low leverage portfolio (Lev1) contains those stocks ranked in the bottom leverage quintile, and high leverage portfolio (Lev5) contains those stocks in the top leverage quintile. We hold long or short positions in these portfolios for the next 12 months (i.e. the holding period).

We follow the same procedure to construct the momentum portfolios, but this time we rank the stocks by cumulative return from July year t-1 to May year t. We skip the month of June to avoid a possible bid-ask bias, Jegadeesh and Titman (1995). Again, we construct five equally weighted portfolios; loser (PR1) portfolio contains the stocks in the bottom past returns quintile, and winner (PR5) portfolio contains those in the top past returns quintile. We hold long or short positions in these portfolios for the next 12 months.

To analyze the relationship between portfolios constructed by these two variables (leverage and momentum), we set up portfolios classifying stocks, according to a double criterion: for each formation date, we create five quintile portfolios, based on leverage (Lev1, Lev2,...Lev5), while independently and simultaneously creating five quintile portfolios, based on momentum (PR1, PR2,..PR5), constructing a total of 25 portfolios.

\footnotetext{
${ }^{3}$ We take leverage data from March because the particular distribution of fiscal year-ends in UK. $41 \%$ of the firms in our sample have December year-ends, and 21\% have March year-ends.
} 
For example, portfolio Lev1 x PR1 (low leverage and losers) comprises those stocks that belong simultaneously to portfolios Lev1 and PR1. This procedure allows us to analyze returns properly to both strategies applied simultaneously. ${ }^{4}$

For every calendar month, we calculate the return that an investor would make if he invested on the 1st July of each year in the portfolios and held these positions for 12 months. The return for each calendar month $t$ can be calculated as an equally weighted average of the portfolio stock returns for that month. In this case, we would assume that throughout the holding period, the portfolios rebalance their composition each month to keep their initial equal weight (i.e. rebalancing portfolios). Another alternative is to maintain the portfolios throughout the holding period without any readjustments (i.e. buyand-hold portfolios). Because, in this case, the portfolios lose their initial equal weight as their stocks draw different returns, it would first be necessary, each calendar month, to obtain the weight of each stock inside the portfolios (see Liu and Strong (2008), eq. 4). Therefore, we opt to use buy-and-hold portfolios over rebalancing portfolios because of their advantages, which include lower transaction costs and the ability to avoid the biases associated with rebalancing portfolios.

Following this procedure, we obtain a return for each calendar month and for each portfolio. We adjust the ex-post CAPM version, running a time-series regression on monthly returns:

$$
\left(R_{p, t}-r\right)=\alpha+\beta\left(R_{M, t}-r_{t}\right)+\varepsilon_{t}
$$

\footnotetext{
${ }^{4}$ The results are robust to other partitions such as deciles and $30 \%-70 \%$ cutoffs.
} 
where $R_{p, t}$ is the return for calendar month $t$ of portfolio $p, r_{t}$ is risk-free asset return on calendar month t, $R_{M, t}$ is the value-weighted market portfolio return on month $\mathrm{t}, \beta$ is market risk, and $\alpha$ is Jensen's alpha, which gauges the abnormal return.

We also report the results obtained when we adjust the ex-post version of the FF to the time-series of monthly returns, running the next time-series regression:

[2] $\left\{\left(R_{p}-r_{t}\right)=\alpha+\beta\left(R_{M, t}-r_{t}\right)+s S M B_{t}+h H M L_{t}+\varepsilon_{t}, \quad t=05 / 81,06 / 81, \ldots, 04 / 12\right\}$

where the SMB and HML factors are calculated following Fama and French (1993). ${ }^{5}$

Alternatively, we also compute the buy-and-hold cumulative market adjusted return over the 12 months after its formation date. This method allows us to obtain the actual return an investor would make in excess of the market portfolio, if he invested in the portfolio and kept it for the entire holding period without making any adjustments ${ }^{6}$ :

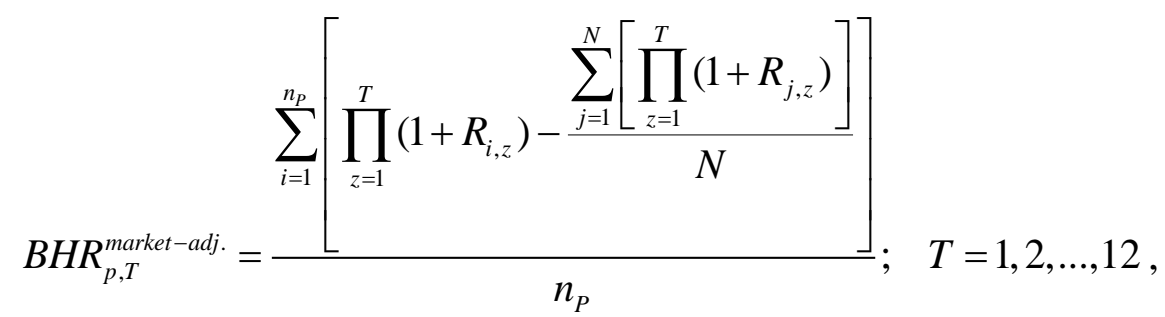

5 Downloaded from http://business-school.exeter.ac.uk/research/areas/centres/xfi/research/famafrench/: Gregory et al. (2013).

${ }^{6}$ Two alternative procedures exist for calculating a portfolio return over an investment period: the additive and the rebalancing. The former does not exactly measure the portfolio whole return throughout the analyzed period, but its average monthly return. The second one implicitly involves an investment strategy that changes the composition of the portfolio month by month to keep the portfolio equally weighted throughout the holding period. In any case, for various reasons, it is the buy-and-hold procedure that has been mainly used in the financial literature. Of these reasons, the price spread bias seems to have less impact on the buy-and-hold procedure, and the rebalancing procedure looks less attractive in terms of transaction costs and, perhaps, less fitted for a medium/long investment horizon (Barber and Lyon, 1997; Blume and Stambaugh, 1983; Liu and Strong, 2008; Lyon et al., 1999). 
where $B H R_{p, T}^{\text {market-adj. }}$ is the buy-and-hold market adjusted return of portfolio $\mathrm{p}$ in the $\mathrm{T}$ months after the formation date, $n_{p}$ is the number of stocks in the portfolio, $\mathrm{N}$ is the total number of stocks in the market, and $R_{i, z}$ is the return of stock $i$ in month $z$ of the holding period.

Lyon et al. (1999) report that an alternative procedure, consisting of returns adjusted by size and BM ratio reference-portfolios, provides more conservative tests than the use the FF. This procedure presents some advantages over the FF. The first is that it does not require linearity in the three factors and allows interaction between them. Furthermore, Mitchell and Stafford (2000) suggest that the FF regression assumes that factor sensibilities are constant throughout time, 384 months in our case. This situation seems quite improbable, since the portfolio composition changes every month. Additionally, Daniel and Titman (1997) note that the average returns cross-section variation is better explained by characteristics than by factor sensitivity.

Bearing this evidence in mind, next we analyze the strategy using the reference portfolio procedure. At the start of each formation month $\mathrm{t}$ (1st July), we construct a total of nine portfolios, according to a double criterion ranking: three size portfolios and three BM ratio portfolios. We use the $30 \%$ and $70 \%$ percentiles as breaking points. Next, we calculate the buy-and-hold returns of these size-BM portfolios for months $t$ to $t+11$. Finally, we take each stock return and subtract the control-portfolio return to which the stock belongs. The leverage and past-returns portfolio returns are calculated with the new adjusted returns. $^{7}$

\footnotetext{
${ }^{7}$ This procedure is similar to that used by Lee and Swaminathan (2000), Moskowitz and Grinblatt (1999) and Nagel (2001), on the analysis of the momentum effect.
} 
We calculate the cumulative return of each portfolio over the 12-month holding period, $z=1,2, . ., 12$, using the buy-and-hold method:

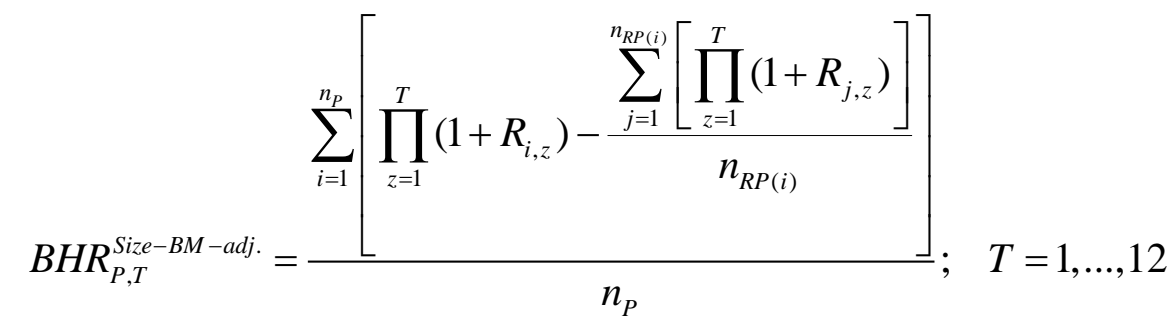

where $B H R_{P, T}^{\text {Size-BM-adj. }}$ is the buy-and-hold size-BM adjusted return of portfolio $P$ over the $T$ first months of the holding period, $n_{P}$ is the number of stocks that form the portfolio, $n_{R P(i)}$ is the number of stocks in the size-BM reference portfolio of stock $i$, and $R_{i, z}$ is the return of stock $i$ in month $z$ of the holding period.

According to Lyon et al. (1999), these two methodological approaches satisfy the condition that the method yields well-specified test statistics in random samples. Though both offer advantages and disadvantages, a pragmatic solution for a researcher who is analyzing long-run abnormal returns would be to use both. ${ }^{8}$

Finally, it is important to consider what happens when a stock is de-listed during the holding period. We decided to replace the de-listed stock return with the average return of the stocks remaining in the portfolio. We reason that if the leverage or momentum effect indeed exists, then the most logical strategy would be to invest the amount obtained, by liquidating the de-listed stock into the portfolio's remaining titles. ${ }^{9}$

\footnotetext{
${ }^{8}$ In both cases, we use buy-and-hold strategies, so we only rebalance the portfolios once a year. The return yield by all the investment strategies we analyze is quite sufficient to compensate common annual rebalancing transaction costs.

${ }^{9}$ Lyon et al. (1999) observe that similar results are achieved using different alternatives.
} 


\section{Empirical Results}

This section presents the return characteristics of leverage and momentum based strategies and the abnormal returns for the portfolios constructed by leverage, momentum, and the intersection of the two. For robustness of results we use both parametric (equations [1] and [2]) and non-parametric (equations [3] and [4]) procedures. The first subsection presents the results for the quintile portfolios constructed by leverage. The second subsection analyzes quintile portfolios constructed by momentum. The third shows the results for the 25 portfolios, resulting from the intersection of the previous leverage and momentum quintiles. Finally, we analyze whether the results are robust for regulated and non-regulated industries.

\subsection{Leverage based trading strategy}

Table 2 presents descriptive properties of the leverage based trading strategy. Panel A shows leverage (\%), size, BM ratio, and past returns (\%) with one-month lag (from July of previous year to end of May). For low (high) leverage portfolio, the average leverage level is $2.09 \%(55.40 \%)$. Low leverage portfolio has the lowest average size (£176.81 millions), and high leverage portfolio has the lowest BM ratio (0.80 times). Past cumulative returns decrease monotonically with leverage ratio, from $20.72 \%$ to $9.88 \%$.

Panel B reports the coefficient estimates from CAPM and FF, as described above in equations [1] and [2], respectively, to account for systematic risk. Alpha indicates the abnormal return earned by the five respective leverage portfolios that range from low leverage to high leverage. The excess return for the low leverage portfolio is $0.38 \%$ per month $(4.66 \%$ per annum) when we use the CAPM, and $0.32 \%$ per month $(3.91 \%$ per annum) when we use the FF. The excess return for the high leverage portfolio is $-0.17 \%$ 
per month (-2.06\% per annum) when we use the CAPM model, and $-0.29 \%$ per month ($3.54 \%$ per annum) when we use the FF. For both models, CAPM and FF, the alphas decrease with leverage. Low leverage portfolio yields significantly positive abnormal returns, and high leverage portfolio yields significantly negative abnormal returns when FF is used. The zero-cost strategy that buys the low leverage portfolio and short-sells the high leverage portfolio, reported in the last column in Panel B, yields a significant abnormal monthly return of $0.55 \%$ (6.80\% per annum) and $0.62 \%$ (7.70\% per annum) for the CAPM and FF models, respectively.

Table 2 here

Following the Lyon et al. (1999) recommendation, in Table 3, we check the robustness of the previous results using a non parametrical risk adjustment. Panel A show annual buy-and-hold returns in excess of the market return, $B H R_{p, T}^{\text {market-adj. }}$ equation [3], and Panel B show annual buy-and-hold returns in excess of the size-BM reference portfolio return, $B H R_{P, T}^{\text {Size-BM-adj. }}$ equation [4]. Market adjusted annual abnormal returns are $3.22 \%$ for the low leverage portfolio, and $-2.78 \%$ for the high leverage portfolio. The trading strategy that buys the low leverage portfolio and sells the high leverage portfolio earns $5.99 \%$ per annum. Size-BM reference annual abnormal returns are $3.47 \%$ for the low leverage portfolio, and $-2.18 \%$ for the high leverage portfolio. The trading strategy that buys the low leverage portfolio and sells the high leverage portfolio earns $5.64 \%$ per annum. These results confirm those observed in Table 2 in that using a strategy based on leverage, it is possible to earn positive abnormal returns. ${ }^{10}$

Table 3 here

\footnotetext{
${ }^{10}$ Results are consistent if firms with Market Value less than 1 million are eliminated.
} 
Panel A of Figure 1 show the size-BM adjusted cumulative returns from equation [4] for each of the twelve months after formation date ( $\left.1^{\text {st }} \mathrm{July}\right)$. Low leverage portfolio positive abnormal cumulative returns increase monotonically throughout the twelve months after the formation date. High leverage portfolio negative abnormal cumulative returns increase in most months. The low minus high leverage strategy increases its positive abnormal cumulative returns in each of the eleven first months after formation date.

\section{Figure 1}

\subsection{Momentum based trading strategy.}

Table 4 presents descriptive properties of the momentum based trading strategy. Panel A shows leverage (\%), size, BM ratio, and past returns (\%) with one-month lag (from July of previous year to end of May). The average leverage is quite similar among all past return portfolios (between $25 \%$ and $26 \%$ ) except for the winner portfolios that shows a lower leverage (22.16\%). For loser portfolio, the average size is $£ 287.82$ million. For median past returns portfolio, the average size is $£ 1,568.30$ million. For high leverage portfolio, the average size is $£ 693.12$ million. Size shows a reversed U-shape, with lower size in the high and low past return portfolios than in the median portfolio. For loser portfolio the average $\mathrm{BM}$ is 1.34 , and for winner portfolio the average $\mathrm{BM}$ is 0.74 . We observe that BM decrease with past returns.

Panel B reports the coefficient estimates from CAPM and FF, as described above in equations [1] and [2], respectively. Alpha indicates the abnormal return earned by the five respective past return portfolios that range from loser to winner. The excess return for the loser portfolio is $0.00 \%$ per month when we use the CAPM, and $-0.19 \%$ per month ( $-2.26 \%$ per annum) when we use the FF model. The excess return for the winner portfolio 
is $0.48 \%$ per month $(5.91 \%$ per annum) when we use the CAPM, and $0.45 \%$ per month (5.54\% per annum) when we use the FF model. For both models, CAPM and FF, winner portfolio yields significantly positive abnormal returns. The zero-cost strategy that buys the winner portfolio and short-sells the loser portfolio, reported in the last column in Panel $\mathrm{B}$, yields a significant abnormal monthly return of $0.48 \%$ (5.91\% per annum), and $0.64 \%$ (7.96\% per annum) for the CAPM and FF models, respectively.

Table 4 here

In Table 5, we check the robustness of the previous results using a nonparametrical risk adjustment. Panel A show the annual buy-and-hold returns in excess of the market return, $B H R_{p, T}^{\text {market-adj. }}$ equation [3], and Panel B show the annual buy-and-hold returns in excess of the size-BM reference portfolio return, $B H R_{P, T}^{S i z e-B M-a d j .}$ equation [4]. Market adjusted annual abnormal returns are $-1.37 \%$ for the loser portfolio, and $6.10 \%$ for the winner portfolio. The trading strategy that buys the loser portfolio and sells the winner portfolio earns $7.47 \%$ per annum. Annual size-BM adjusted returns (\%) are $2.84 \%$ for the loser portfolio, and $7.02 \%$ for the winner portfolio. The trading strategy that buys the winner portfolio and sells the loser portfolio earns $9.85 \%$ per annum. These results confirm those observed in Table 4 in that using a strategy based on past returns, it is possible to earn annual returns above $6 \%$ per annum.

Panel B of Figure 1 shows the size-BM adjusted cumulative returns from equation [4] for each of the twelve months after formation date ( $\left.1^{\text {st }} \mathrm{July}\right)$. Winner portfolio positive abnormal cumulative returns increase throughout the nine months after the formation date. Loser portfolio negative abnormal cumulative returns yield also mainly in the first nine months after formation date, and are weaker than those yielded by the winner 
portfolio. The winner minus loser strategy increases its positive abnormal cumulative returns in each of the nine months after formation date.

Table 5 here

\subsection{Leverage and Momentum based trading strategy}

Table 6 reports the alpha estimates from CAPM and FF, as described above in equations [1] and [2], respectively. Alpha indicates the abnormal return earned by the 25 leverage past return portfolios. Our results show that among the 25 leverage past return portfolios, significant positive abnormal returns are widespread in all winner portfolios independently of their leverage level. Winner portfolios yield significant positive abnormal returns in all leverage subsamples: $0.50 \%, 0.37 \%, 0.39 \%, 0.40 \%$ and $0.53 \%$ monthly for the FF (between $4.53 \%$ and $6.55 \%$ in annual terms). However, the negative abnormal returns are concentrated among losers with high leverage, and are inexistent among losers stocks with low leverage. For example, the portfolios Lev5-PR1 and Lev5PR2 yield the higher negative abnormal returns: a statistically significant $-0.72 \%$ and $0.71 \%$ monthly for the FF, respectively $(-8.31 \%$ and $-8.20 \%$ per annum); but the portfolios Lev1-PR1 and Lev2-PR1 alphas are not significant (the CAPM alpha for the Lev1-PR1 portfolios is even positive at the $10 \%$ level of significance)

Our results are important to enhance momentum strategies. Although leverage does not matter when selecting winner stocks, loser stocks should be selected among high leverage stocks. For example, the last rows of Table 6 report the abnormal returns for the strategy that combines both leverage and momentum (winner-low - loser-high strategy). This strategy, which buys winner stocks with low leverage and short-sells loser stocks with high leverage, yield significant monthly abnormal returns of $0.99 \%(12.55 \%$ in annual terms) for the CAPM, and $1.22 \%$ (15.66\% in annual terms) for the FF. However, 
the strategy that buys winner stocks with high leverage and short-sells loser stocks with low leverage (winner-high - loser-low strategy) only yields a non-significant $0.03 \%$ monthly for the CAPM, and $0.14 \%$ monthly for the FF. Moreover, the winner-low - loserhigh strategy yield higher abnormal returns than strategies based in only one of these variables. The two-dimension strategy yields $1.22 \%$ monthly FF alphas. The single leverage strategy yields $0.62 \%$ and single momentum strategy $0.64 \%$. The difference (more than 7\% higher returns in annual terms) is statistically and economically significant with t-statistics of 2.52 and 2.79 respectively. ${ }^{11}$

Our results also show that the negative relation between abnormal returns and leverage, observed in unconditional leverage portfolios (Table 2), only keep significant for the non-winner subsample. For PR1, PR2, and PR3 subsamples, the low minus high leverage strategies yield significant CAPM monthly abnormal returns of 1.03\%, $0.96 \%$ and $0.66 \%(13.08 \%, 12.15 \%$, and $8.21 \%$ in annual terms) and significant FF abnormal returns of $1.10 \%, 1.06 \%$, and $0.74 \%(14.03 \%, 13.49 \%$, and $9.25 \%$ in annual terms. The positive relation between CAPM and FF abnormal returns and past returns observed in unconditional momentum portfolios (Table 4) only keep significant for the non-low leverage subsample. For Lev3, Lev4, and Lev5 subsamples, the momentum strategies yield significant CAPM monthly abnormal returns of $0.69 \%, 0.69 \%$ and $1.06 \%(8.60 \%$, $8.60 \%$, and $13.49 \%$ in annual terms) and significant FF abnormal returns of $0.79 \%$, $0.83 \%$, and $1.25 \%(9.90 \%, 10.43 \%$, and $16.08 \%$ in annual terms.

If we consider leverage as proxy of default risk, our evidence of nonexistence of momentum among low leveraged stocks is consistent with Avramov et al. (2007) who find that momentum is concentrated among stocks with low credit ratings; and our evidence that negative returns are exclusive for high leverage stocks is consistent with

\footnotetext{
${ }^{11}$ Similar results are obtained independently of what winner portfolio was bought.
} 
Agarwal and Taffler (2008) who show that negative abnormal returns are concentrated among losers and default stocks. But contrary to the results of Avramov et al. (2007) and Agarwal and Taffler (2008), our results shows that if leverage is considered as proxy of default risk, momentum profits are not exclusive of default stocks as in Avramov et al. (2007), and momentum returns are not only driven by the bad return trend earned by distress stocks as in Agarwal and Taffler (2008). In our opinion our differentiating results are quite useful to the implementation of investment strategies given that, contrary to Avramov et al. (2007) and Agarwal and Taffler (2008), with low leverage winners stocks it is possible to have positive abnormal returns avoiding sort-sell positions and default stocks.

Table 6 here

In Table 7, we check the robustness of the previous results, using a nonparametrical risk adjustment. Abnormal returns are the annual buy-and-hold returns in excess of the market return, $B H R_{p, T}^{\text {market-adj. }}$ equation [3] (Panel A), and in excess of the sizeBM reference portfolio return, $B H R_{P, T}^{S i z e-B M-a d j .}$ equation [4] (Panel B). The results are quite consistent with those reported in Table 6. Winner portfolios' over-performance is widespread independently of the leverage level: with the exception of the annual market adjusted returns of the winners-Lev 2 and winners-Lev3 portfolios, all winner portfolios yield significant positive abnormal returns. And loser portfolio undeperformace is concentrated in loser stocks with high leverage levels: for example, Loser-Lev5 portfolio yields a significant $-6.28 \%$ market adjusted return, and a significant $-7.43 \%$ size-BM adjusted returns. Moreover, low minus high leverage strategy profits are located in loser subsamples. For PR1, and PR2 subsamples, the annual market adjusted returns are a significant $11.24 \%$, and $11.34 \%$ respectively, and the annual size-BM adjusted returns 
are a significant $12.21 \%$, and $8.49 \%$, respectively. Momentum profits are concentrated in non-low leverage subsamples (Lev3, Lev4, and Lev5): the annual market adjusted return are a significant $11.12 \%, 9.45 \%$, and $13.87 \%$ respectively, and the annual size-BM adjusted return are a significant $14.76 \%, 12.48 \%$, and $15.87 \%$.

Table 7 here

\subsection{Bootstrap robustness test}

Given that the Jarque-Bera test broadly rejects the normality hypothesis for most of the portfolios' cumulative returns series (equations 3 and 4), we check the robustness of our results, using a bootstrap analysis to compute the p-values. In particular, we use the procedure proposed by Lyon et al. (1999), who apply the bootstrap method to the tstatistic, adjusted for asymmetry developed by Johnson (1978). We apply this methodology, using 10,000 repetitions with replacement and bootstrap samples of the same size as the original sample; that is, 31 observations. Lyon et al. (1999) showed that this bootstrap procedure for the buy-and-hold returns, adjusted with size-BM reference portfolios (equation 4), yield well specified test statistics in random samples. The bootstrap test confirms the robustness of the results for all portfolios. These results are not reported but are available to any interested parties.

\subsection{Non-regulated firms subsample}

Muradoglu and Sivaprasad (2012a) demonstrate that the negative relation between abnormal returns and leverage is limited to firms in non-regulated industries. Boni and Womack (2006) provide evidence that an industry-based recommendation strategy substantially improves the return to risk ratio, and reduces price momentum relative to 
portfolios that ignore industry information. Thus, in this subsection, we check the robustness of the previous results for the subsample of non-regulated industries.

Table 8 presents descriptive properties of the leverage based trading strategy for the non-regulated subsample. This subsample includes all industries, except Telecommunications and Utilities (SIC codes 6000 and 7000, respectively). Panel A shows averages for leverage (\%), size, BM ratio, and past returns. Panels B and C report the annual buy-and-hold returns in excess of the market return, $B H R_{p, T}^{\text {market-adj. }}$ equation [3], and in excess of the size-BM reference portfolio return, $B H R_{P, T}^{S i z e-B M-a d j}$ equation [4], respectively.

The majority of the firms in the sample belong to the non-regulated industries, and the results for this subsample are quite similar to those observed for the full sample. For low leverage portfolio, the average leverage level is $1.99 \%$, the average size is $£ 153.83$ million, the average $\mathrm{BM}$ is 0.99 , and average past return of $20.59 \%$. For high leverage portfolio, the average leverage level is $54.95 \%$, the average size is $£ 1197.11$ million, the average $\mathrm{BM}$ is 0.81 , and average past return is $9.95 \%$. Annual market adjusted returns are $3.34 \%$ for the low leverage portfolio and $-3.03 \%$ for the high leverage portfolio. The trading strategy that buys the low leverage portfolio and sells the high leverage portfolio earns $6.38 \%$ per annum. Annual size-BM adjusted returns are $3.61 \%$ for the low leverage portfolio and $-2.39 \%$ for the high leverage portfolio. The trading strategy that buys the low leverage portfolio and sells the high leverage portfolio earns $6.00 \%$ per annum.

Table 8 here

Table 9 reports the results for the 25 leverage-momentum portfolios. The results are also quite similar to those observed in the full sample. Winner portfolios overperformance is widespread independently of the leverage level: with the exception of the 
annual market adjusted returns of the Lev1, Lev2, and Lev3 subsamples, all winner portfolios yield significant positive abnormal returns. And loser portfolio undeperformace is concentrated in loser stocks with high leverage levels: for example, Loser-Lev5 portfolio yields a significant $-6.40 \%$ market adjusted return, and a significant $-7.61 \%$ sizeBM adjusted returns. Moreover, low minus high leverage strategy profits are located in the loser subsamples. For PR1, and PR2 subsamples, the annual market adjusted returns are a significant $12.01 \%$, and $11.22 \%$, respectively, and the annual size-BM adjusted returns are a significant $12.65 \%$, and $8.24 \%$, respectively. Momentum profits are concentrated in non-low leverage subsample. For Lev5 subsample, the annual market adjusted return is a significant $12.84 \%$, and the annual size-BM adjusted return is a significant $15.03 \% .^{12}$

Table 9 here

\section{Conclusion}

The purpose of this study is to use the interaction between leverage and momentum as the basis of a trading strategy. Our results show that, although in average low leverage stocks outperform high leverage stocks, this outperformance is not observed among winner stocks; and that although in general winner stocks outperform loser stocks, this outperformance is not observed among low leveraged stocks. Moreover, we find that negative abnormal returns are exclusive of those stocks that are simultaneously losers and have high leverage; but positive abnormal returns are shown in winner stocks independently of their leverage level.

\footnotetext{
${ }^{12}$ The CAPM and FF adjusted abnormal returns are quite similar. These results are not reported but are available from authors upon request.
} 
If we consider leverage as proxy of default risk, our finding that winner stocks yield positive abnormal returns for all leverage categories point out that, discordant to previous evidence, we cannot conclude that momentum profits are exclusive of distressed stocks (Avramov et al., 2007) nor momentum is exclusively driven by bad return trend of distressed stocks (Agarwal and Taffler, 2008). On the contrary, our results show that the best way to take advantage of the interaction between momentum and leverage is to buy winner stocks (independently of their leverage level) and short sell high leverage loser stocks. When this combined leverage-momentum strategy is implemented, we observe a significant abnormal return that are higher than the single strategies.

The strategy that buys low leverage winner stocks and short sell high leverage losers stocks yield FF adjusted returns of $1.22 \%$ monthly (almost $16 \%$ annually) that is statistically and economically higher that of the single leverage strategy $(0.62 \%)$ and the single momentum strategy $(0.64 \%)$ both of which yield about $8 \%$ annually; the difference is almost $8 \%$. The major implication of our findings to investors is that an investment strategy based on leverage and momentum provides enhanced profits compared to using these strategies independently. Moreover, investing in those stocks that simultaneously are past winners and have low leverage ratios investors can reach significant returns investing in non-default stocks and without requiring short-sales. We demonstrate that our results are robust to non-normality using a bootstrap analysis to compute the p-values, and that our conclusion remain for the subsample of non-regulated industries.

We suggest further avenues for future research. It would be interesting to expand the scope of these tests for the effect of leverage on other trading strategies. For example one could jointly investigate the evidence from leverage portfolios and long term overreaction. The fact that average returns decline with leverage makes it possible to contrast the predictions of rational leverage theory with those of behavioural theory 
through a demand side analysis. It could be noteworthy to identify investor preferences for low leverage and high momentum. It would be remarkable to identify similar preferences in other contexts such as analysts' forecasts or foreign direct investments. 


\section{REFERENCES}

Abinzano, I., L. Muga, and R. Santamaria. 2014. "Is default risk the hidden factor in momentum returns? Some empirical results." Accounting and Finance, vol. 54, no. 3 (September): 671-698.

Agarwal, V., and R. Taffler. 2008. "Does Financial Distress Risk Drive the Momentum Anomaly?" Financial Management, vol. 37, no. 3 (Autumn): 461-484.

Avramov, D., T. Chordia, G. Jostova, and A. Philipov. 2007. "Momentum and Credit Rating." Journal of Finance, vol. 62, no. 5 (October): 2503-2520.

Barber, B. M., and J. D. Lyon. 1997. "Detecting long-run abnormal stock returns: the empirical power and specification of test statistics." Journal of Financial Economics, vol. 43, no.3 (March): 341-372.

Bhandari, L. C. 1988. "Debt/Equity Ratio and Expected Common Stock Returns: Empirical Evidence.” Journal of Finance, vol. 43, no. 2 (June): 507-528.

Blume, M., and R. Stambaugh. 1983. "Biases in computed returns: an application to the size effect." Journal of Financial Economics, vol. 12, no. 3 (November): 387-404.

Boni, L., and K. L. Womack. 2006. “Analysts, Industries, and Price Momentum.” Journal of Financial and Quantitative Analysis, vol. 41, no. 1 (March): 85-109.

Booth, G.G., H-G Fung, and W.K. Leung. 2016. "A risk-return explanation of the momentum-reversal "anomaly"." Journal of Empirical Finance, vol. 35 (January): 68-77.

Campbell, J. Y., J. Hilscher, and J. Szilagyi. 2008. "In Search of Distress Risk.” Journal of Finance, vol. 63, no. 6 (December): 2899-2939.

Chordia, T., and L. Shivakumar. 2002. "Momentum, business cycle, and time-varying expected returns.” Journal of Finance, vol. 57, no. 2 (April): 985-1019. 
Chui, A., S. Titman, and K. C. Wei. 2003. "Momentum, Legal Systems and Ownership Structure: An Analysis of Asian Stock Markets.” Working paper, University of Texas at Austin.

Chui, A., S. Titman, and K. C. Wei. 2010. "Individualism and momentum around the world.” Journal of Finance, vol. 65, no. 1 (February): 361-392.

Conrad, J., and G. Kaul. 1998. "An anatomy of trading strategies”, Review of Financial Studies, vol. 11, no. 3: 489-519.

Daniel, K., and S. Titman. 1997. "Evidence on the Characteristics of Cross Sectional Variation in Stock Returns.” Journal of Finance, vol. 52, no. 1 (March): 1-33.

Daniel, K., and S. Titman. 1999. "Market Efficiency in an Irrational World.”. Financial Analysts Journal, vol. 55, no. 6 (November/December): 28-40.

Dhaliwal, D., S. Heitzman, and L. Zhen. 2006. "Taxes, leverage, and the cost of equity capital.” Journal of accounting research, vol. 44, no. 4 (September): 691-723.

Dichev, I. D. 1998. "Is the Risk of Bankruptcy a Systematic Risk?” Journal of Finance, vol. 53, no. 3 (June): 1131-1147.

Dimitrov, V., and P. C. Jain. 2008. "The Value Relevance of Changes in Financial Leverage beyond Growth in Assets and GAAP Earnings.” Journal of Accounting, Auditing and Finance, vol. 23, no. 2 (April): 191-222.

Fama, E. 1998. "Market efficiency, long-term returns, and behavioural finance.” Journal of Financial Economics, vol. 49, no. 3 (September): 283-306.

Fama, E., and K. R. French. 1992. “The cross-section in expected stock returns.” Journal of Finance, vol. 47, no. 2 (June): 427-466.

Fama, E. and K. R. French. 1993. "Common risk factors in the returns on stock and bonds." Journal of Financial Economics, vol. 33, no. 1 (February), 3-56. 
Garlappi, L., T. Shu, and H. Yan. 2008. "Default Risk, Shareholder Advantage, and Stock Returns." Review of Financial Studies, vol. 21, no. 6: 2743-2778.

Geczy,C.C., and M. Samonov. 2016. "Two Centuries of Price-Return Momentum." Financial Analysts Journal, vol. 72, no. 5 (September/October): 32-56.

George, T. J., and C. Y. Hwang. 2010. "A resolution of the distress risk and leverage puzzles in the cross section of stock returns." Journal of Financial Economics, vol. 96, no. 1 (April): 56-79.

Gomes, J. F., and L. Schmid. 2010. "Levered Returns.” Journal of Finance, vol. 65, no. 2 (April): 467-494.

Gregory, A., R. Tharyan, and A. Christidis. 2013. "Constructing and Testing Alternative Versions of the Fama-French and Carhart Models in the UK." Journal of Business Finance \& Accounting, vol. 40,no. 1-2 (January/February): 172-214.

Griffin, J., and L. Lemmon. 2002. "Book-to-Market Equity, Distress Risk, and Stock Returns.” Journal of Finance, vol. 57, no. 5 (October): 2317-2336.

Hamada, R.S. 1972. "The Effect of the Firm's Capital Structure on the Systematic Risk of Common Stocks.” Journal of Finance, vol. 27, no. 2 (May): 435-452.

Hong, H., T. Lim, and C. Stein. 2000. "Bad news travels slowly: size, analyst coverage, and the profitability of momentum strategies." Journal of Finance, vol. 55, no. 1 (February): 265-295.

Jegadeesh, N., and S. Titman. 1993. "Returns to Buying Winners and Selling Losers: Implications for Stock Market Efficiency.” Journal of Finance, vol. 48, no. 1 (march): 65-91.

Jegadeesh, N., and S. Titman. 1995. "Short horizon return reversals and the bid-ask spread." Journal of Financial Intermediation, vol. 4, no. 2 (April): 116-133. 
Jegadeesh, N., and S. Titman. 2001. "Profitability of Momentum Strategies: An Evaluation of Alternative Explanations." Journal of Finance, vol. 56, no. 2 (April): 699-720.

Jegadeesh, N., and S. Titman. 2002. "Cross-sectional and time-series determinants of momentum returns", Review of Financial Studies, vol. 15, no. 1: 143-157.

Johnson, N.J. 1978. "Modified t tests and confidence intervals for asymmetrical populations." Journal of the American Statistical Association, vol. 73: 536-544.

Johnson, T. C. 2002. "Rational momentum effects.” Journal of Finance, vol. 57, no. 2 (April): 585-608.

Korteweg, A., 2010. “The net benefits of leverage.” Journal of Finance, vol. 65, no. 6 (December): 2137-2170.

Lee, C. M. C., and B. Swaminathan. 2000. "Price momentum and trading volume." Journal of Finance, vol. 55, no. 5 (October): 2017-2069.

Liew, J., and M. Vassalou. 2000. “Can Book-to-Market, Size, and Momentum be Risk Factors that Predict Economic Growth?” Journal of Financial Economics, vol. 57, no. 2 (August): 221-245.

Liu, W., and N. Strong. 2008. "Biases in decomposing holding period portfolio returns." Review of Financial Studies, vol. 21, no. 5: 2243-2274.

Liu, W., N. Strong, and X. Xu. 1999. “The Profitability of Momentum Investing.” Journal of Business Finance \& Accounting, vol. 26, no. 9-10 (November/December): 10431091.

Lyon, J. D., B. M. Barber, and C. Tsai. 1999. "Improved methods for test of long-run abnormal stock returns.” Journal of Finance, vol. 54, no. 1 (February), 165-201. 
Mao, M. Q., and K.C. J. Wei. 2014. "Price and earnings momentum: An explanation using return decomposition." Journal of Empirical Finance, vol 28 (September): $332-351$

Mitchell, M. L., and E. Stafford. 2000. "Managerial Decisions and Long Term Stock Price Performance.” Journal of Business, vol. 73, no. 3 (July): 287-329.

Modigliani F., and M. H. Miller. 1958. "The Cost of Capital, Corporation Finance and the Theory of Investment." American Economic Review, vol. 48, no. 3 (June): 261297.

Moskowitz, T.J., and M. Grinblatt. 1999. “Do Industries Explain Momentum?” Journal of Finance, vol. 54, no. 4 (August): 1249-1290

Muradoglu, G., and S. Sivaprasad. 2012a. "Using Firm-Level Leverage as an Investment Strategy." Journal of Forecasting, vol. 31, no. 3 (April): 260-279.

Muradoglu, G., and S. Sivaprasad. 2012b. "Capital Structure and Abnormal Returns." International Business Review, vol. 21, no. 3 (June): 328-341.

Nagel, S. 2001. "Is it overreaction? The performance of value and momentum strategies at long Horizons.” Paper presented at 29th European Financial Association Annual Meeting - Barcelona, Spain. DOI: 10.2139/ssrn.276290.

Penman, S. H., S. A. Richardson, and I. Tuna. 2007. "The book-to-price effect in stock returns: accounting for leverage." Journal of Accounting Research, vol. 45, no. 2 (May): 427-467.

Rouwenhorst, K. G. 1998. "International Momentum Strategies.” Journal of Finance, vol. 53, no.1 (February): 267-284.

Strong, N., and X. G. Xu. 1997. "Explaining the cross-section of UK expected stock returns." British Accounting Review, vol. 29, no. 1 (March). 1-23.

Welch. I., 2016 “Levered Returns”, NBER Working Paper 22150 (April). 
$\mathrm{Wu}, \mathrm{X}$. 2002. "A conditional multifactor analysis of return momentum." Journal of Banking and Finance, vol. 26, no. 8 (August): 1675-1696. 
TABLE 1

SUMMARY STATISTICS

\begin{tabular}{lccccc}
\hline Variable & Mean & Std.Dev. & 25th Pctl. & Median & 75th Pctl. \\
\hline PANEL A & & & & & \\
\hline Monthly returns & $0.870 \%$ & $18.000 \%$ & $-5.873 \%$ & $0.000 \%$ & $5.986 \%$ \\
SIZE & 1075.407 & 5675.127 & 14.790 & 62.180 & 316.220 \\
BM & 1.063 & 4.430 & 0.300 & 0.552 & 1.000 \\
Leverage & 0.248 & 0.223 & 0.032 & 0.218 & 0.392 \\
\hline
\end{tabular}

TABLE 2

\section{LEVERAGE PORTFOLIOS MONTHLY RETURNS}

Quintiles portfolios constructed by leverage (Lev). Firms are ranked $1^{\text {st }}$ July year " $\mathrm{t}$ " according to their leverage at previous March. Panel A show raw monthly returns (\%), leverage (\%), size (market value in millions), BM ratio, and past 11-month cumulative returns (\%) with one month lag. Panel B shows montly abnormal returns (\%) and factor loadings from CAPM and FF model (equations [1] and [2]). Standard p-values in brackets. Last column shows the zero-cost strategy that buys the low leverage portfolio and short-sells the high leverage portfolio.

\begin{tabular}{|c|c|c|c|c|c|c|}
\hline & Lev1 (low) & Lev2 & Lev3 & Lev4 & Lev5 (high) & low-high \\
\hline \multicolumn{7}{|c|}{ PANEL A: Characteristics } \\
\hline Leverage \% & 2.09 & 9.71 & 21.82 & 34.50 & 55.40 & \\
\hline Size & 176.81 & 622.17 & 1091.63 & 1500.91 & 1332.35 & \\
\hline $\mathrm{BM}$ & 0.98 & 0.93 & 1.03 & 0.96 & 0.80 & \\
\hline Past Return & 20.72 & 17.29 & 14.50 & 15.30 & 9.88 & \\
\hline
\end{tabular}

PANEL B: CAPM and FF abnormal returns

\begin{tabular}{|c|c|c|c|c|c|c|c|c|c|c|c|c|}
\hline & CAPM & $\mathrm{FF}$ & CAPM & $\mathrm{FF}$ & CAPM & FF & CAPM & $\mathrm{FF}$ & CAPM & $\mathrm{FF}$ & CAPM & FF \\
\hline \multirow[t]{2}{*}{ alpha\% } & 0.38 & 0.32 & 0.16 & 0.09 & -0.04 & -0.14 & 0.05 & -0.06 & -0.17 & -0.29 & 0.55 & 0.62 \\
\hline & $(0.06)$ & $(0.02)$ & $(0.33)$ & (0.39) & $(0.77)$ & $(0.12)$ & $(0.71)$ & $(0.52)$ & $(0.31)$ & $(0.01)$ & $(0.00)$ & $(0.00)$ \\
\hline \multirow[t]{2}{*}{ Market } & 0.83 & 0.82 & 0.84 & 0.83 & 0.85 & 0.84 & 0.93 & 0.91 & 0.93 & 0.91 & -0.10 & -0.09 \\
\hline & $(0.00)$ & $(0.00)$ & $(0.00)$ & $(0.00)$ & $(0.00)$ & $(0.00)$ & $(0.00)$ & $(0.00)$ & $(0.00)$ & $(0.00)$ & $(0.00)$ & $(0.00)$ \\
\hline \multirow[t]{2}{*}{ SMB } & & 0.86 & & 0.76 & & 0.65 & & 0.71 & & 0.83 & & 0.02 \\
\hline & & $(0.00)$ & & $(0.00)$ & & $(0.00)$ & & $(0.00)$ & & $(0.00)$ & & $(0.61)$ \\
\hline \multirow[t]{2}{*}{ HML } & & -0.17 & & -0.09 & & 0.07 & & 0.09 & & 0.08 & & -0.25 \\
\hline & & $(0.00)$ & & $(0.01)$ & & $(0.01)$ & & $(0.00)$ & & $(0.01)$ & & $(0.00)$ \\
\hline R-adjusted & 0.47 & 0.73 & 0.57 & 0.81 & 0.67 & 0.87 & 0.68 & 0.88 & 0.60 & 0.84 & 0.02 & 0.10 \\
\hline
\end{tabular}


TABLE 3

\section{LEVERAGE PORTFOLIOS ANNUAL RETURNS}

Quintiles portfolios constructed by leverage (Lev). Firms are ranked $1^{\text {st }}$ July year " $t$ " according to their leverage at previous March. Panel A shows annual market adjusted returns (\%) from the equation [3]. Panel B shows annual sizeBM adjusted returns (\%) from the equation [4]. Last column shows the zero-cost strategy that buys the low leverage portfolio and short-sells the high leverage portfolio.

\begin{tabular}{|c|c|c|c|c|c|c|}
\hline & Lev1 (low) & Lev2 & Lev3 & Lev4 & Lev5 (high) & low-high \\
\hline \multicolumn{7}{|c|}{ PANEL A: Annual buy-and-hold Market adjusted returns (\%): Equation [4]: $B H R_{p, T}^{\text {market-adj. }}$} \\
\hline Returns \% & 3.22 & 0.72 & -1.85 & -0.04 & -2.78 & 5.99 \\
\hline p-val & $(0.06)$ & $(0.44)$ & $(0.12)$ & $(0.97)$ & $(0.05)$ & $(0.02)$ \\
\hline \multicolumn{7}{|c|}{ PANEL B: Annual buy-and-hold size-BM adjusted returns (\%) : Equation [5]: $B H R_{P, T}^{S i z e-B M-a d j .}$} \\
\hline Returns $\%$ & 3.47 & 0.54 & -2.59 & -0.32 & -2.18 & 5.64 \\
\hline p-val & $(0.02)$ & $(0.53)$ & $(0.02)$ & $(0.75)$ & $(0.08)$ & $(0.02)$ \\
\hline
\end{tabular}

TABLE 4

\section{MOMENTUM PORTFOLIOS MONTHLY RETURNS}

Quintiles portfolios constructed by past returns (PR). Firms are ranked $1^{\text {st }}$ July year " $t$ ", according to their return in the 11 month period from July year "t-1" to May year " $t$ " (one month lag to avoid microestructure bias). Panel A show leverage (\%), size (market value), BM ratio, and 11 month past returns (\%) with one-month lag. Panel B shows montly abnormal returns (\%) and factor loadings from CAPM and FF model (equations [1] and [2]). Standard pvalues in brackets. Last column shows the zero-cost strategy that buys the winner portfolio and short-sells the loser portfolio: momentm strategy.

\begin{tabular}{|c|c|c|c|c|c|c|}
\hline & $\begin{array}{c}\text { PR1 } \\
\text { (loser) }\end{array}$ & PR 2 & PR 3 & PR 4 & $\begin{array}{c}\text { PR5 } \\
\text { (winner) }\end{array}$ & winner-loser \\
\hline \multicolumn{7}{|c|}{ PANEL A: Characteristics } \\
\hline Leverage\% & 25.04 & 26.09 & 26.24 & 25.18 & 22.16 & \\
\hline Size & 287.82 & 948.50 & 1568.30 & 1310.70 & 693.12 & \\
\hline $\mathrm{BM}$ & 1.34 & 1.07 & 0.84 & 0.81 & 0.74 & \\
\hline Past returns & -36.98 & -8.40 & 8.02 & 26.24 & 88.01 & \\
\hline
\end{tabular}

PANEL B: CAPM and FF abnormal returns

\begin{tabular}{|c|c|c|c|c|c|c|c|c|c|c|c|c|}
\hline & CAPM & $\mathrm{FF}$ & CAPM & $\mathrm{FF}$ & CAPM & $\mathrm{FF}$ & CAPM & $\mathrm{FF}$ & CAPM & $\mathrm{FF}$ & CAPM & $\mathrm{FF}$ \\
\hline \multirow[t]{2}{*}{ alpha\% } & 0.00 & -0.19 & -0.14 & -0.24 & -0.01 & -0.09 & 0.14 & 0.08 & 0.48 & 0.45 & 0.48 & 0.64 \\
\hline & (1.00) & $(0.27)$ & $(0.40)$ & $(0.04)$ & $(0.96)$ & $(0.28)$ & $(0.30)$ & $(0.34)$ & $(0.01)$ & $(0.00)$ & $(0.01)$ & $(0.00)$ \\
\hline \multirow[t]{2}{*}{ Market } & 0.95 & 0.92 & 0.89 & 0.87 & 0.82 & 0.81 & 0.83 & 0.82 & 0.90 & 0.89 & -0.05 & -0.03 \\
\hline & $(0.00)$ & $(0.00)$ & $(0.00)$ & $(0.00)$ & $(0.00)$ & $(0.00)$ & $(0.00)$ & $(0.00)$ & $(0.00)$ & $(0.00)$ & $(0.24)$ & $(0.45)$ \\
\hline \multirow[t]{2}{*}{ SMB } & & 1.09 & & 0.73 & & 0.63 & & 0.61 & & 0.78 & & -0.31 \\
\hline & & $(0.00)$ & & $(0.00)$ & & $(0.00)$ & & $(0.00)$ & & $(0.00)$ & & $(0.00)$ \\
\hline \multirow[t]{2}{*}{ HML } & & 0.22 & & 0.07 & & 0.02 & & -0.07 & & -0.21 & & -0.43 \\
\hline & & $(0.00)$ & & $(0.06)$ & & $(0.52)$ & & $(0.01)$ & & $(0.00)$ & & $(0.00)$ \\
\hline R-adjusted & 0.43 & 0.72 & 0.60 & 0.80 & 0.68 & 0.87 & 0.67 & 0.85 & 0.57 & 0.81 & 0.00 & 0.17 \\
\hline
\end{tabular}


TABLE 5

\section{MOMENTUM PORTFOLIOS ANNUAL RETURNS}

Quintiles portfolios constructed by past returns (PR). Firms are ranked $1^{\text {st }}$ July year " $\mathrm{t}$ ", according to their return in the 11 month period from July year "t-1" to May year " $y$ " (one month lag to avoid microestructure bias). Panel A shows annual market adjusted returns (\%) from the equation [3], standard p-values, skewness, Jarque-Bera p-values, and Bootstrapped skewness adjusted t-statistic p-values. Panel B shows annual size-BM adjusted returns (\%) from the equation [4]. Last column shows the zero-cost strategy that buys the winner portfolio and short-sells the loser portfolio: the momentum strategy.

\begin{tabular}{cccccc}
$\begin{array}{c}\text { PR1 } \\
\text { (loser) }\end{array}$ & PR 2 & PR 3 & PR 4 & $\begin{array}{c}\text { PR5 } \\
\text { (winner) }\end{array}$ & winner-loser \\
\hline
\end{tabular}

PANEL A: Annual buy-and-hold Market adjusted returns (\%): Equation [4]: $B H R_{p, T}^{\text {market-adj }}$

\begin{tabular}{ccccccc}
\hline Returns\% & -1.37 & -3.00 & -1.93 & 0.39 & 6.10 & 7.47 \\
p-val & $(0.45)$ & $(0.00)$ & $(0.06)$ & $(0.72)$ & $(0.00)$ & $(0.02)$ \\
\hline
\end{tabular}

PANEL B: Annual buy-and-hold size-BM adjusted returns (\%) : Equation [5]: $B H R_{P, T}^{\text {Size-BM-adj. }}$

\begin{tabular}{ccccccc}
\hline Returns\% & -2.84 & -3.74 & -1.83 & 1.03 & 7.02 & 9.85 \\
p-val & $(0.05)$ & $(0.00)$ & $(0.02)$ & $(0.27)$ & $(0.00)$ & $(0.00)$ \\
\hline
\end{tabular}




\section{TABLE 6}

\section{LEVERAGE AND PAST RETURNS PORFOLIOS MONTHLY RETURNS}

25 portfolios from the intersection of leverage (Lev) quintiles and past returns (PR) quintiles. Panel A shows montly abnormal returns (\%) from CAPM and FF model (equations [1] and [2]). Standard p-values in brackets. Last rows show the strategy that buys the winner low leverage firms and short-sells the loser high leverage firms, as well as the strategy that buys the winner high leverage firms and short-sells the loser low leverage firms.

\begin{tabular}{|c|c|c|c|c|c|c|c|}
\hline \multirow{2}{*}{\multicolumn{8}{|c|}{$\begin{array}{ll}\text { Lev1 (low) } & \text { Lev2 } \\
\text { PANEL A. CAPM and FF abnormal returns }\end{array}$}} \\
\hline & & & & & & & \\
\hline \multirow[t]{3}{*}{ PR1 } & CAPM-alpha & $\begin{array}{c}0.55 \\
(0.88)\end{array}$ & $\begin{array}{c}0.20 \\
(0.56)\end{array}$ & $\begin{array}{c}-0.24 \\
(0.33)\end{array}$ & -0.21 & -0.48 & $\begin{array}{c}1.03 \\
(0.00)\end{array}$ \\
\hline & FF-alpha & 0.38 & 0.02 & -0.40 & -0.43 & -0.72 & 1.10 \\
\hline & & $(0.16)$ & $(0.95)$ & $(0.05)$ & $(0.07)$ & $(0.00)$ & $(0.00)$ \\
\hline \multirow[t]{4}{*}{ PR2 } & CAPM-alpha & 0.39 & 0.08 & -0.38 & -0.13 & -0.57 & 0.96 \\
\hline & & $(0.14)$ & $(0.68)$ & $(0.04)$ & $(0.53)$ & $(0.01)$ & $(0.00)$ \\
\hline & FF-alpha & 0.35 & -0.02 & -0.50 & -0.26 & -0.71 & 1.06 \\
\hline & & $(0.14)$ & $(0.90)$ & $(0.00)$ & $(0.12)$ & $(0.00)$ & $(0.00)$ \\
\hline \multirow[t]{4}{*}{ PR3 } & CAPM-alpha & 0.36 & -0.01 & -0.06 & -0.14 & -0.30 & 0.66 \\
\hline & & $(0.08)$ & $(0.94)$ & $(0.70)$ & $(0.32)$ & $(0.08)$ & $(0.00)$ \\
\hline & FF-alpha & 0.34 & -0.09 & -0.16 & -0.25 & -0.40 & 0.74 \\
\hline & & $(0.04)$ & $(0.51)$ & $(0.17)$ & $(0.04)$ & $(0.00)$ & $(0.00)$ \\
\hline \multirow[t]{4}{*}{ PR4 } & CAPM-alpha & 0.19 & 0.23 & 0.12 & 0.13 & -0.01 & 0.20 \\
\hline & & $(0.36)$ & $(0.23)$ & $(0.43)$ & $(0.43)$ & (0.98) & (0.39) \\
\hline & FF-alpha & 0.13 & 0.19 & 0.06 & 0.07 & -0.05 & 0.18 \\
\hline & & $(0.46)$ & $(0.23)$ & $(0.66)$ & $(0.62)$ & $(0.77)$ & $(0.45)$ \\
\hline \multirow[t]{4}{*}{ PR5 } & CAPM-alpha & 0.52 & 0.36 & 0.45 & 0.47 & 0.59 & 0.07 \\
\hline & & $(0.03)$ & $(0.07)$ & $(0.02)$ & $(0.01)$ & $(0.01)$ & $(0.78)$ \\
\hline & FF-alpha & 0.50 & 0.37 & 0.39 & 0.40 & 0.53 & 0.02 \\
\hline & & $(0.01)$ & $(0.02)$ & $(0.01)$ & $(0.01)$ & $(0.01)$ & $(0.93)$ \\
\hline \multirow{2}{*}{\multicolumn{2}{|c|}{ Momentum CAPM-alpha }} & -0.03 & 0.17 & 0.69 & 0.69 & 1.06 & \\
\hline & & $(0.91)$ & $(0.62)$ & $(0.00)$ & $(0.01)$ & $(0.00)$ & \\
\hline & FF-alpha & 0.12 & 0.35 & 0.79 & 0.83 & 1.25 & \\
\hline & & $(0.66)$ & $(0.28)$ & $(0.00)$ & $(0.00)$ & $(0.00)$ & \\
\hline & CAPM-alpha & \multirow{2}{*}{\multicolumn{2}{|c|}{ winner-low - loser-high }} & 0.99 & \multirow{2}{*}{\multicolumn{2}{|c|}{ winner-high - loser-low }} & 0.03 \\
\hline & & & & $(0.00)$ & & & $(0.92)$ \\
\hline & FF-alpha & & & 1.22 & & & 0.14 \\
\hline & & & & $(0.00)$ & & & $(0.64)$ \\
\hline \multicolumn{8}{|c|}{ PANEL B: Average number of stocks } \\
\hline \multicolumn{2}{|l|}{ PR1 } & 35 & 23 & 23 & 21 & 28 & \\
\hline \multicolumn{2}{|l|}{ PR2 } & 26 & 23 & 27 & 25 & 28 & \\
\hline \multicolumn{2}{|l|}{ PR3 } & 23 & 22 & 28 & 29 & 27 & \\
\hline \multicolumn{2}{|l|}{ PR4 } & 24 & 23 & 27 & 30 & 25 & \\
\hline \multicolumn{2}{|l|}{ PR5 } & 34 & 26 & 25 & 24 & 21 & \\
\hline
\end{tabular}


TABLE 7

LEVERAGE AND PAST RETURNS PORTFOLIOS ANNUAL RETURNS

25 portfolios from the intersection of leverage (Lev) quintiles and past returns (PR) quintiles. Panel A shows annual market adjusted returns (\%) from the equation [3] and standard p-values. Panel B shows annual sizeBM adjusted returns (\%) from the equation [4]. Last rows for each Panel show the strategy that buys the winner low leverage firms and short-sells the loser high leverage firms, as well as the strategy that buys the winner high leverage firms and short-sells the loser low leverage firms.

\begin{tabular}{ccccccc}
\hline & Lev1 (low) & Lev2 & Lev3 & Lev4 & $\begin{array}{c}\text { Lev5 } \\
\text { (high) }\end{array}$ & low-high \\
\hline PANEL A: Annual buy-and-hold Market adjusted returns (\%): Equation [4]: & BHR $R_{p, T}^{\text {market-adj. }}$ \\
\hline PR1 (losers) & 4.96 & 0.35 & -4.04 & -3.19 & -6.28 & 11.24 \\
& $(0.12)$ & $(0.91)$ & $(0.10)$ & $(0.27)$ & $(0.03)$ & $(0.01)$ \\
PR2 & 3.77 & -0.58 & -6.99 & -2.06 & -7.57 & 11.34 \\
& $(0.12)$ & $(0.78)$ & $(0.00)$ & $(0.38)$ & $(0.00)$ & $(0.00)$ \\
PR3 & 2.27 & -1.48 & -2.81 & -3.50 & -4.71 & 6.98 \\
& $(0.53)$ & $(0.39)$ & $(0.17)$ & $(0.16)$ & $(0.06)$ & $(0.12)$ \\
PR4 & 0.04 & 2.03 & 0.09 & 0.88 & -1.35 & 1.39 \\
& $(0.98)$ & $(0.40)$ & $(0.97)$ & $(0.53)$ & $(0.58)$ & $(0.67)$ \\
PR5 (winners) & 6.01 & 3.97 & 7.08 & 6.27 & 7.58 & -1.58 \\
& $(0.04)$ & $(0.16)$ & $(0.06)$ & $(0.01)$ & $(0.01)$ & $(0.67)$ \\
Momentum & 1.05 & 3.62 & 11.12 & 9.45 & 13.87 & \\
& $(0.83)$ & $(0.47)$ & $(0.02)$ & $(0.02)$ & $(0.00)$ & \\
\hline winner-low - loser-high & 12.29 & winner-high - loser-low & 2.63 & & \\
& $(0.01)$ & & & $(0.50)$ & & \\
\hline
\end{tabular}

PANEL B: Annual buy-and-hold size-BM adjusted returns (\%) : Equation [5]: $B H R_{P, T}^{S i z e-B M-a d j .}$

\begin{tabular}{ccccccc}
\hline PR1 (losers) & 4.78 & -0.43 & -7.64 & -5.94 & -7.43 & 12.21 \\
& $(0.14)$ & $(0.88)$ & $(0.00)$ & $(0.04)$ & $(0.01)$ & $(0.01)$ \\
PR2 & 1.75 & -1.35 & -8.01 & -3.53 & -6.74 & 8.49 \\
& $(0.38)$ & $(0.46)$ & $(0.00)$ & $(0.11)$ & $(0.00)$ & $(0.00)$ \\
PR3 & 1.15 & -1.91 & -3.62 & -2.15 & -2.98 & 4.13 \\
& $(0.71)$ & $(0.22)$ & $(0.06)$ & $(0.25)$ & $(0.22)$ & $(0.32)$ \\
PR4 & 0.93 & 2.18 & 1.17 & 1.31 & -0.22 & 1.15 \\
& $(0.56)$ & $(0.34)$ & $(0.53)$ & $(0.31)$ & $(0.92)$ & $(0.70)$ \\
PR5 (winners) & 8.35 & 4.81 & 7.12 & 6.54 & 8.45 & -0.09 \\
& $(0.00)$ & $(0.04)$ & $(0.03)$ & $(0.01)$ & $(0.00)$ & $(0.98)$ \\
Momentum & 3.58 & 5.24 & 14.76 & 12.48 & 15.87 & \\
& $(0.43)$ & $(0.24)$ & $(0.00)$ & $(0.00)$ & $(0.00)$ & \\
\hline \multirow{2}{*}{ winner-low - loser-high } & 15.78 & winner-high- loser-low & 3.67 & & \\
& $(0.00)$ & & $(0.35)$ & & \\
\hline
\end{tabular}


TABLE 8

\section{LEVERAGE PORTFOLIOS ANNUAL RETURNS FOR NON-REGULATED INDUSTRIES}

Non-regulated industries subsample: all industries, except Telecomunications (6000) and Utilities (7000). Quintiles portfolios constructed by leverage (Lev). Firms are ranked $1^{\text {st }}$ July year "t", according to their leverage at previuos March. Panel A shows leverage (\%), size (market value), BM ratio, and 11month past returns with one month lag. Panel B shows annual market adjusted returns (\%) from the equation [3], and standard p-values. Panel C shows annual sizeBM adjusted returns (\%) from the equation [4], and standard p-values. Last column shows the zero-cost strategy that buys the low leverage portfolio and short-sells the high leverage portfolio.

\begin{tabular}{|c|c|c|c|c|c|c|}
\hline & Lev1 (low) & Lev2 & Lev3 & Lev4 & Lev5 (high) & low-high \\
\hline \multicolumn{7}{|c|}{ PANEL A: Characteristics } \\
\hline Leverage & 1.99 & 9.60 & 21.56 & 34.17 & 54.95 & \\
\hline Size & 153.83 & 511.19 & 975.47 & 1315.53 & 1197.11 & \\
\hline $\mathrm{BM}$ & 0.99 & 0.94 & 1.02 & 0.97 & 0.81 & \\
\hline Past_return & 20.59 & 17.81 & 14.53 & 15.23 & 9.95 & \\
\hline
\end{tabular}

PANEL B: Annual buy-and-hold Market adjusted returns (\%): Equation [4]: $B H R_{p, T}^{\text {market-adj. }}$

$\begin{array}{ccccccc}\text { Returns\% } & 3.34 & 0.76 & -1.88 & 0.11 & -3.04 & 6.38 \\ \text { p-val } & (0.06) & (0.43) & (0.15) & (0.93) & (0.03) & (0.02)\end{array}$

PANEL C: Annual buy-and-hold size-BM adjusted returns (\%) : Equation [5]: $B H R_{P, T}^{S i z e-B M-a d j \text {. }}$

\begin{tabular}{ccccccc}
\hline Returns\% & 3.61 & 0.55 & -2.61 & -0.27 & -2.39 & 6.00 \\
p-val & $(0.02)$ & $(0.53)$ & $(0.03)$ & $(0.78)$ & $(0.06)$ & $(0.02)$ \\
\hline
\end{tabular}


TABLE 9

LEVERAGE AND PAST RETURNS PORTFOLIOS ANNUAL RETURNS FOR NONREGULATED INDUSTRIES

Non-regulated industries subsample: all industries, except Telecomunications (6000) and Utilities (7000). 25 portfolios from the intersection of leverage quintiles and momentum quintiles. Panel A shows annual market adjusted returns (\%) from the equation [3] and standard p-values. Panel B shows annual size-BM adjusted returns (\%) from the equation [4]. Last rows for each Panel show the strategy that buys the winner low leverage firms and short-sells the loser high leverage firms, as well as the strategy that buys the winner high leverage firms and short-sells the loser low leverage firms.

\begin{tabular}{ccccccc}
\hline & Lev1 (low) & Lev2 & Lev3 & Lev4 & Lev5 (high) & low-high \\
\hline \multirow{2}{*}{ PANEL A: Annual buy-and-hold Market adjusted returns (\%): Equation [4]: } & BHR $R_{p, T}^{\text {market-adj. }}$ & \\
\hline PR1 (losers) & 5.60 & 0.76 & -5.66 & -0.94 & -6.40 & 12.01 \\
PR2 & $(0.08)$ & $(0.80)$ & $(0.02)$ & $(0.79)$ & $(0.04)$ & $(0.01)$ \\
& 3.46 & -1.39 & -6.49 & -2.89 & -7.76 & 11.22 \\
PR3 & $(0.14)$ & $(0.51)$ & $(0.00)$ & $(0.19)$ & $(0.00)$ & $(0.00)$ \\
& 2.99 & -1.11 & -2.83 & -3.63 & -4.49 & 7.48 \\
PR4 & $(0.48)$ & $(0.58)$ & $(0.16)$ & $(0.15)$ & $(0.08)$ & $(0.15)$ \\
& 0.33 & 1.96 & -0.18 & 1.25 & -1.74 & 2.07 \\
PR5 (winners) & $(0.85)$ & $(0.44)$ & $(0.93)$ & $(0.34)$ & $(0.47)$ & $(0.51)$ \\
& 5.61 & 4.47 & 6.74 & 6.78 & 6.44 & -0.83 \\
Momentum & $(0.07)$ & $(0.10)$ & $(0.08)$ & $(0.00)$ & $(0.03)$ & $(0.84)$ \\
& 0.01 & 3.71 & 12.39 & 7.72 & 12.84 & $(0.00)$ \\
\hline \multirow{2}{*}{ winner-low - loser-high } & $(0.45)$ & $(0.02)$ & $(0.07)$ & 0.84 & $(0.84)$ \\
\hline
\end{tabular}

PANEL B: Annual buy-and-hold size-BM adjusted returns (\%) : Equation [5]: $B H R_{P, T}^{S i z e-B M-a d j}$.

\begin{tabular}{ccccccc}
\hline PR1 (losers) & 5.03 & -0.02 & -9.21 & -4.20 & -7.61 & 12.65 \\
\multirow{2}{*}{ PR2 } & $(0.12)$ & $(1.00)$ & $(0.00)$ & $(0.23)$ & $(0.01)$ & $(0.01)$ \\
& 1.49 & -2.28 & -7.47 & -3.79 & -6.75 & 8.24 \\
PR3 & $(0.45)$ & $(0.23)$ & $(0.00)$ & $(0.07)$ & $(0.00)$ & $(0.01)$ \\
& 1.82 & -1.32 & -3.58 & -2.71 & -2.71 & 4.53 \\
PR4 & $(0.62)$ & $(0.46)$ & $(0.05)$ & $(0.17)$ & $(0.29)$ & $(0.34)$ \\
& 1.36 & 2.08 & 0.65 & 1.80 & -0.51 & 1.87 \\
PR5 (winners) & $(0.39)$ & $(0.38)$ & $(0.71)$ & $(0.16)$ & $(0.80)$ & $(0.51)$ \\
& 8.17 & 5.40 & 6.91 & 6.99 & 7.42 & 0.75 \\
Momentum & $(0.00)$ & $(0.02)$ & $(0.04)$ & $(0.01)$ & $(0.01)$ & $(0.84)$ \\
& 3.13 & 5.42 & 16.11 & 11.19 & 15.03 & $(0.00)$ \\
\hline \multirow{2}{*}{ winner-low - loser-high } & $(0.48)$ & 15.78 & winner-high - loser-low & 2.39 & \\
& & & & $(0.55)$ & \\
\hline
\end{tabular}


Figure 1

\section{SIZE-BM ADJUSTED CUMULATIVE RETURNS THROUGHOUT THE 12 MONTHS AFTER THE FORMATION DATE}

Size-BM adjusted cumulative returns from the equation [5] for each of the twelve months after formation date (1st July). Panel A: Quintiles portfolios constructed by leverage. Firms are ranked 1st July year "t", according to their leverage at previous March. Panel B: Quintiles portfolios constructed by past returns. Firms are ranked 1st July year "t", according to their return in the 11 month period from July year "t-1" to May year "t" (one month lag to avoid microestructure bias).

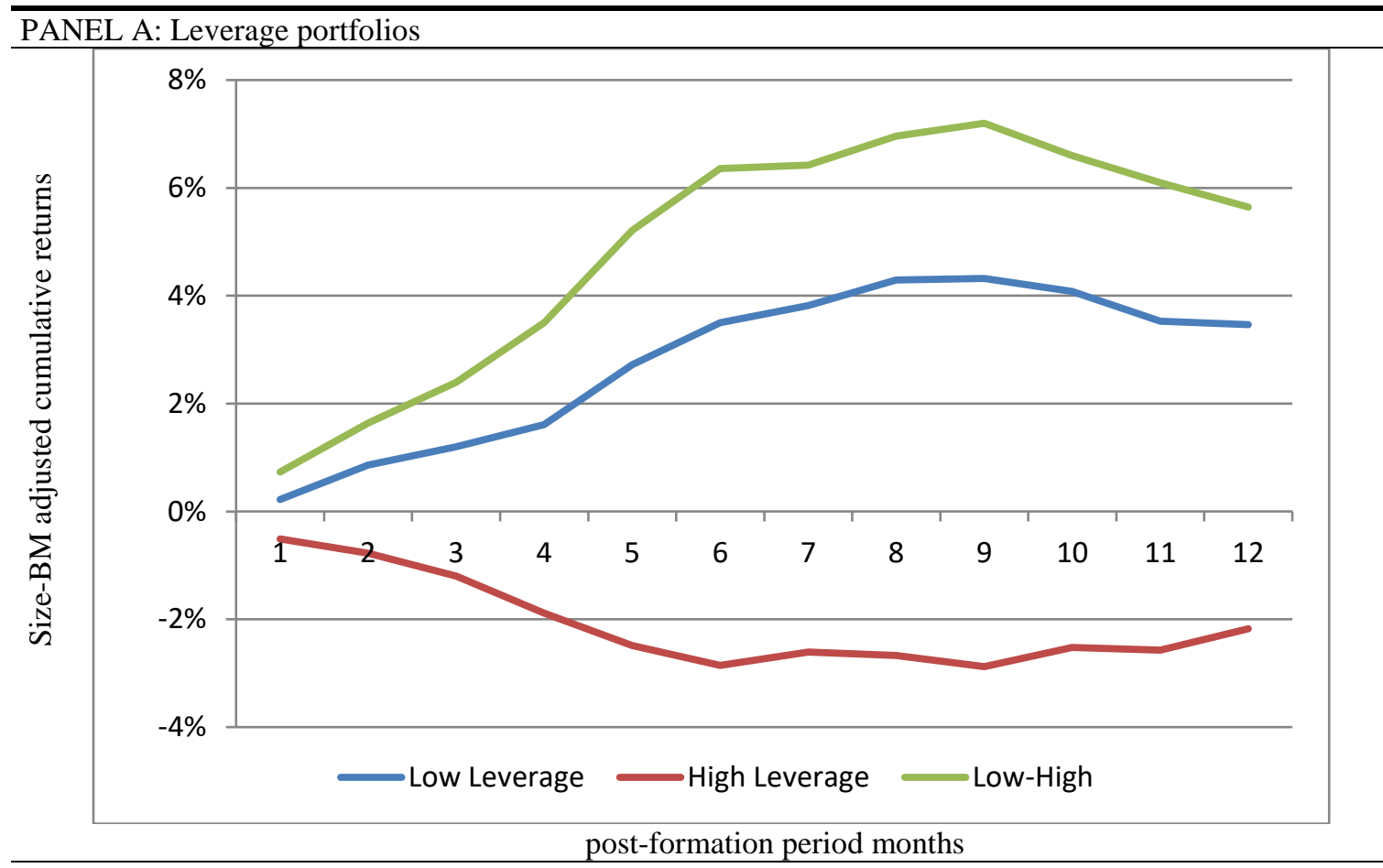

\section{PANEL B: Past-return portfolios}

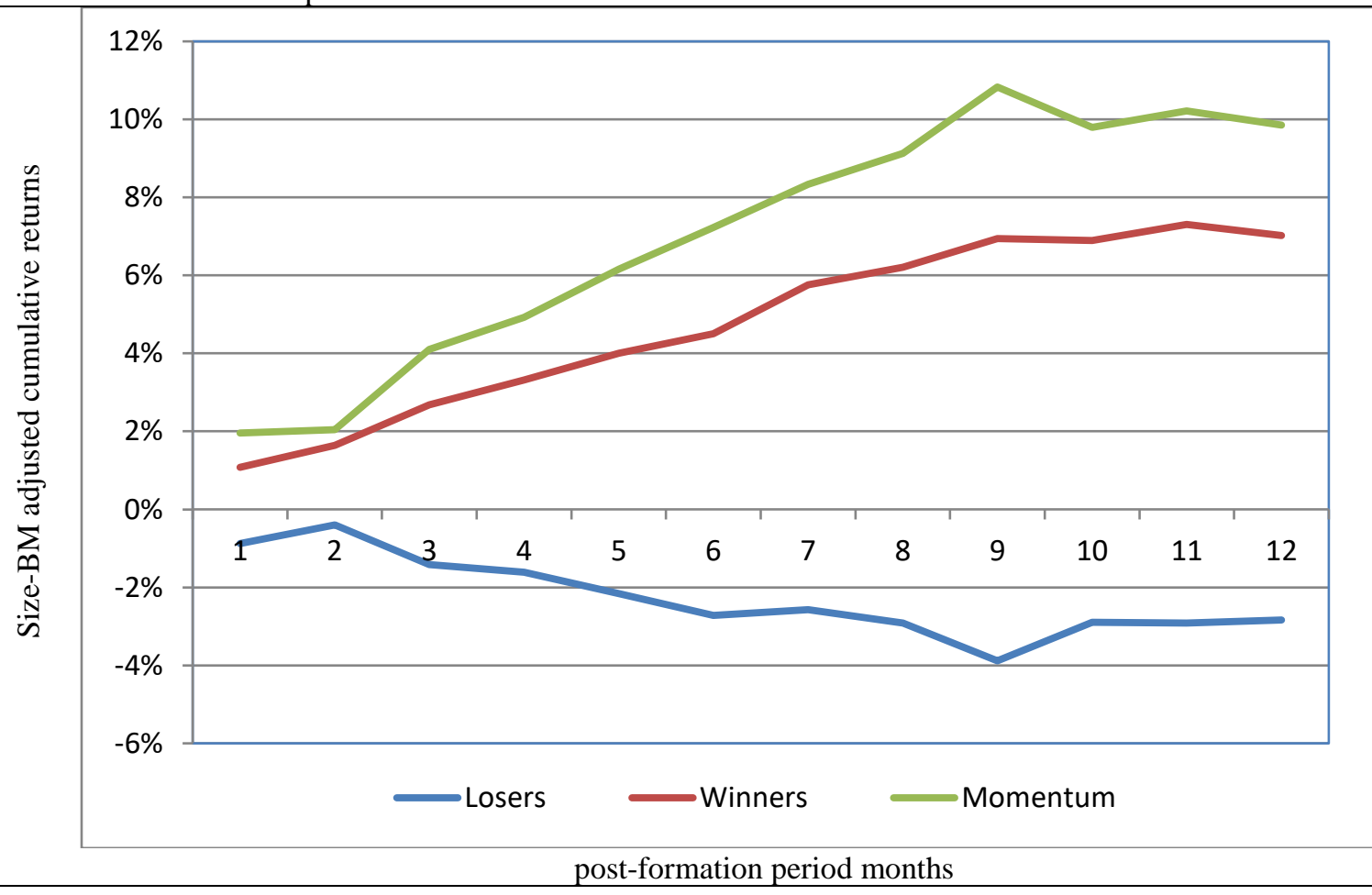


